\title{
Reproductivity in Inbred Strains of Mice and Project for Their Efficient Production
}

\author{
Hiroshi NAGASAWA, Moriyoshi MIYAMOTO and Masaharu FUJIMOTO \\ National Cancer Center Research Institute, Tsukiji 5-1-1, Chuo-ku, Tokyo 104
}

(Received for publication: December 7, 1972)

\begin{abstract}
Reproductivities of mother mice of inbred strains were investigated and a project for their efficient production was made on the basis of the data of reproductivity. Inbred strains of mice used were $\mathrm{C} 3 \mathrm{HeB} / \mathrm{FeJax}, \mathrm{C} 3 \mathrm{H} / \mathrm{HeMs}, \mathrm{C} 57 \mathrm{BL} / 6 \mathrm{Jax}, \mathrm{CBA}, \mathrm{BALB} / \mathrm{cHe}, \mathrm{A}, \mathrm{RIII}$ and DBA/2, which were maintained by sister $\mathrm{x}$ brother mating in our laboratory. After 70 days of age, each female was mated with a male and concurrent pregnancy was planned until the 3rd lactation. Interval between litters was approximately 4 weeks in all strains except BALB/cHe, of which interval was about 5 weeks (Fig. 1). There was marked difference in litter size among strains; the largest was 6.4 in $\mathrm{C} 3 \mathrm{HeB} / \mathrm{FeJax}$ and $\mathrm{C} 3 \mathrm{H} / \mathrm{HeMs}$ and the smallest was 4.2 in $\mathrm{DBA} / 2$ (Fig. 2). Normal parturition ratio was better in $\mathrm{C} 3 \mathrm{HeB} / \mathrm{FeJax}, \mathrm{C} 3 \mathrm{H} / \mathrm{HeMs}, \mathrm{CBA}, \mathrm{C} 57 \mathrm{BL} / 6 \mathrm{Jax}$ and $\mathrm{A}$ than in $\mathrm{BALB} / \mathrm{cHe}$, RIII and $\mathrm{DBA} / 2$ (Fig. 3 ). The rearing ratio on day 20 of lactation was lower in RIII, DBA/2 and A than in the other strains (Fig. 4). As shown in Table 2, strains with larger mothers had a trend to produce larger pups than strains with smaller mothers, while there was no large differences among strains in the pups' growth ratio. From the data shown in Tables 1 and 2 and Figs. 1-4, it would be considered that the reproductivity was better in order of $\mathrm{C} 3 \mathrm{HeB} / \mathrm{FeJax}, \mathrm{C} 3 \mathrm{H} / \mathrm{HeMs} \ldots \ldots \mathrm{DBA} / 2$. The results of interval between litters indicate that numbers of groups starting mating are 5 and $4 \mathrm{in} \mathrm{BALB} / \mathrm{cHe}$ and in the other strains, respectively, to produce weanling pups every week (Fig. 5 ). Number of parents required per group is obtained by the following formula ;
\end{abstract}

Number of weanling pups to be produced

Rearing ratio on day $20 \times$ litter size $\times$ normal parturition ratio

and number of cages required is to be obtained by multiplying mumber of parents per group with number of groups. For example, number of parents or cages required in each strain for production of 100 weanling pups a week is presented in Table 3. Number of cages was the smallest in $\mathrm{C} 3 \mathrm{HeB} / \mathrm{FeJax}$ (76) and the largest in $\mathrm{DBA} / 2$ (200) which is to need more cages than twice of those of $\mathrm{C} 3 \mathrm{HeB} / \mathrm{FeJax}$. The order of number of parents or cages necessary for production of 100 weanling pups a week was in accord with the order of reproductivity. [Exp. Animals, 22(2), 119-126, 1973] 


\title{
系統マウスの繁殖成績と計画生産について
}

\author{
長澤弘, 宮本 盛吉, 藤本 政晴 \\ 国立がんセンター研究所 \\ 東京都中央区築地 5-1-1
}

癌研究用実験動物として各種の系統マウスが用いられ ているが，著者らの研究所においても $\mathrm{C} 3 \mathrm{H} / \mathrm{HeMs}, \mathrm{C} 57$ BL/6Jax, CBA, BALB/cHe, A, RIII, DBA/2 など の系統 マウスが用いられている。Festing [2]によれ ば，癌研究用として使用されているマウスのうち75\%以 上は，上記系統のマウスによって占められているとい う。著者らはこれら系統マウスのほかに $\mathrm{C} 3 \mathrm{HeB} / \mathrm{FeJax}$ (C3H の受精卵を $\mathrm{C} 57 \mathrm{BL} / 6$ の子宮に移植して得た mammary tumor virus free の系統) を加えた 8 系統 マウスの系統維持ならびに繁殖を行なっているが，これ ら系統マウスの生産を効率よく行ならためには，その動 物のもつ繁殖性についてのデータを基にして計画をたて る必要がある。しかし繁殖性に関する量的な諸形質は, 環境の影響を受けやすく[5]，同一系統マウスでもその 繁殖性に関し研究者によって值の違うことが指摘されて いる[1]。したがって他所に持けるデータをそのまま適 用することは必ずしも妥当でなく，一定の環境下に㧤い てみずからが把握した基礎データを用いることが大切で ある。

以上の観点から, 著者らは当研究所で系統繁殖してい る上記の 8 系統マウスについてその繁殖性を調べ，これ らの成績に基づいた生産方法, とくに追いかけ妊娠 (Concurrent pregnancy) 方式*による計画生産につ いての一試案を作成した。

\section{材料および方法}

動物は当研究所で系統繁殖している8 系統のマウス, すなわち $\mathrm{C} 3 \mathrm{HeB} / \mathrm{FeJax}\left(\mathrm{F}_{58}\right), \mathrm{C} 3 \mathrm{H} / \mathrm{HeMs}\left(\mathrm{F}_{?+45}\right)$, C57BL/6Jax $\left(\mathrm{F}_{88}\right), \mathrm{CBA}\left(\mathrm{F}_{132}\right), \mathrm{BALB} / \mathrm{cHe}\left(\mathrm{F}_{130}\right)$, A $\left(\mathrm{F}_{?+25}\right)$, RIII $\left(\mathrm{F}_{?+33}\right), \mathrm{DBA} / 2\left(\mathrm{~F}_{?+22}\right)$ を用いた。 各系統とも固型飼料（日本クレア $\mathrm{KK}$, 繁殖用 C A-1） 扣よび水を自由に与え, 温度 $24 \pm 0.5^{\circ} \mathrm{C}$, 相対湿度 $65 \sim$ $70 \%$, 午前 8 時から午後 8 時までの 12 時間照明に規制し た飼育室に捻いて，ポリカーボネート製ケージ（18×27

* 雌雄を常時同居させておくことによって, 毎回の分 婏後発情時の受胎を図ること。したがって理想的に は，動物は常に妊娠しながら泌乳していることにな る。 $\times 13 \mathrm{~cm} ）$ に雌雄別に 6 匹ずつ収容した。床敷は週 2 回交 換し, ケージ交換は 3 週間毎に行なった。また飼育器材 はそれぞれ乾熱, 惹沸, 高圧滅菌処理したものを用い た。

交配方法は，70日齢に達した雌雄各 1 を同居させ， 3 産まで追いかけ妊娠させた。繁殖成績としては前報〔4] に準じて, 各系統とも個体, 産次ごとに交配分婏間隔, 産子数, 分婏時母体重, $0,12,20$ 日齢平均子体重, 12 日齢子増体率，12，20日齢育成率，繁殖不能個体率（回 数)，死産子率などを 3 産まで調べた。

これらの繁殖成績を用いて，追いかけ妊娠方式による 週単位を基準（毎週 100 匹生産）とした計画生産のため の生産群の編成, 生産親ならびにケージ数の算出を行な った。

\section{結果および考察}

\section{I. 繁殖成縝}

母マウスの繁殖成績を Table 1 抢よび Figs. $1 \sim 4$ に示した。交配分婏間隔においては，1産では系統間に 大きなひらきはなく，1産あたりの平均所要日教は約 4 週間であったが, $\mathrm{BALB} / \mathrm{cHe}$ のみが 2 産, 3 産と産次 が進むにつれて長くなり，1産あたりの平均所要日数は 約 5 週間となった(Fig. 1)。

産子数においては系統内産次間で顕著な変動はみられ なかったが，系統間においては違いが認められた。すな わち $\mathrm{C} 3 \mathrm{HeB} / \mathrm{FeJax}, \mathrm{C} 3 \mathrm{H} / \mathrm{HeMs}$ では平均 6.4 匹であ ったが，A，DBA/2 ではそれぞれ4.9匹，4.2匹と他系 にくらべて少なかった (Fig. 2)。

分婏時母体重に打いては，各系統とも産次が進むにつ れて増加する傾向がみられたが，系統間では母体重の比 較的大きいグループ，すなわち， C3H/HeMs, BALB/ $\mathrm{cHe}, \mathrm{C} 3 \mathrm{HeB} / \mathrm{FeJax}, \mathrm{CBA}, \mathrm{C} 57 \mathrm{BL} / 6 \mathrm{Jax}$ と, 小さい グループ A, DBA/2, RIII とに分かれた。また母体重 の大きいグループでは，産子数の多い傾向を示した。

正常分婏率の変化を Fig. 3 に示す。C $3 \mathrm{HeB} / \mathrm{FeJax}$, $\mathrm{CBA}, \mathrm{C} 57 \mathrm{BL} / 6 \mathrm{Jax}, \mathrm{C} 3 \mathrm{H} / \mathrm{HeMs}, \mathrm{A}$ に沶いては各産次 を通じて $90 \%$ しくはそれ以上であったが，BALB/ $\mathrm{cHe}, \mathrm{R}$ III, DBA/2 では 1 産の $80 \%$ 前後から 3 産の70\% 


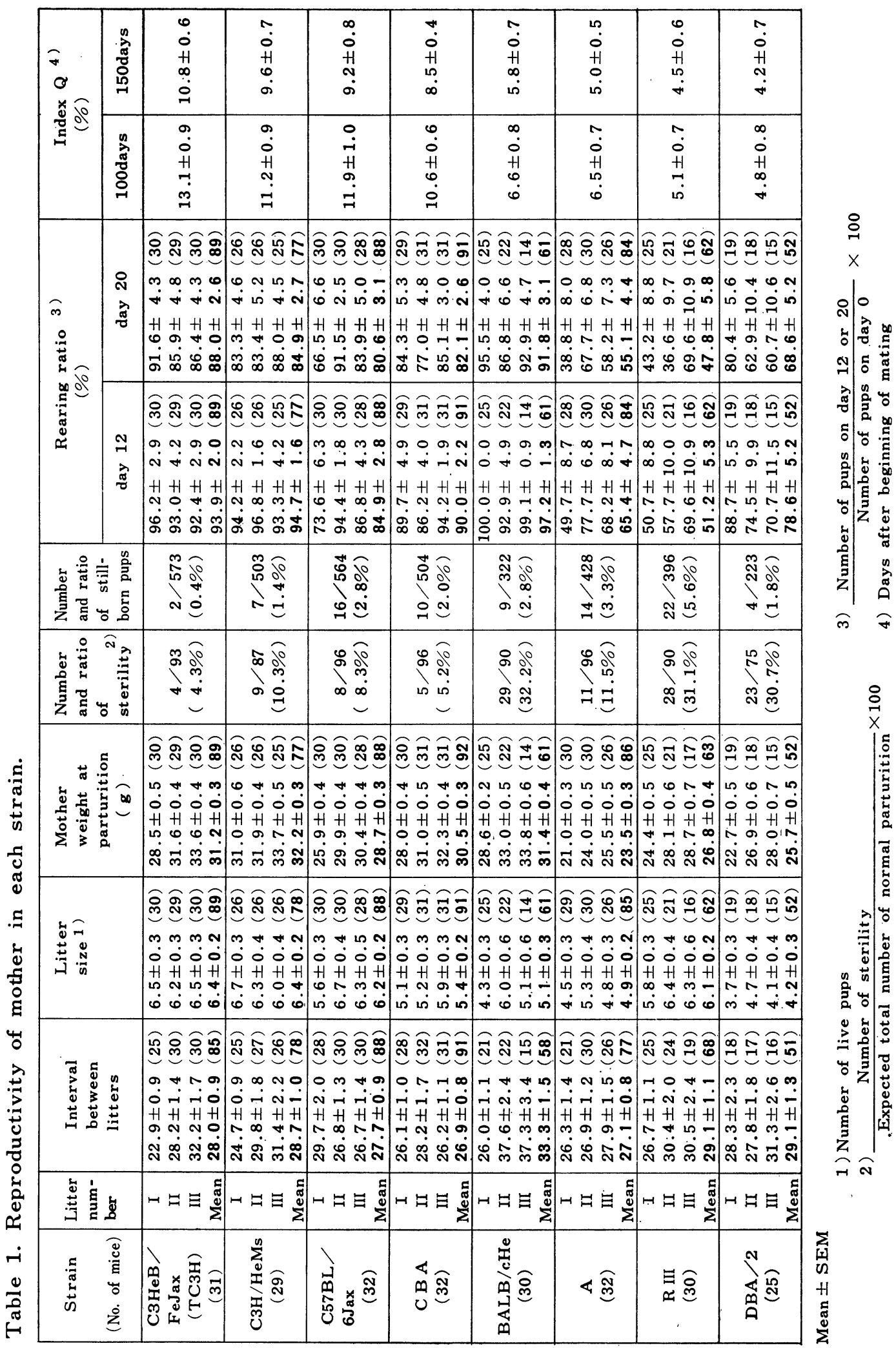




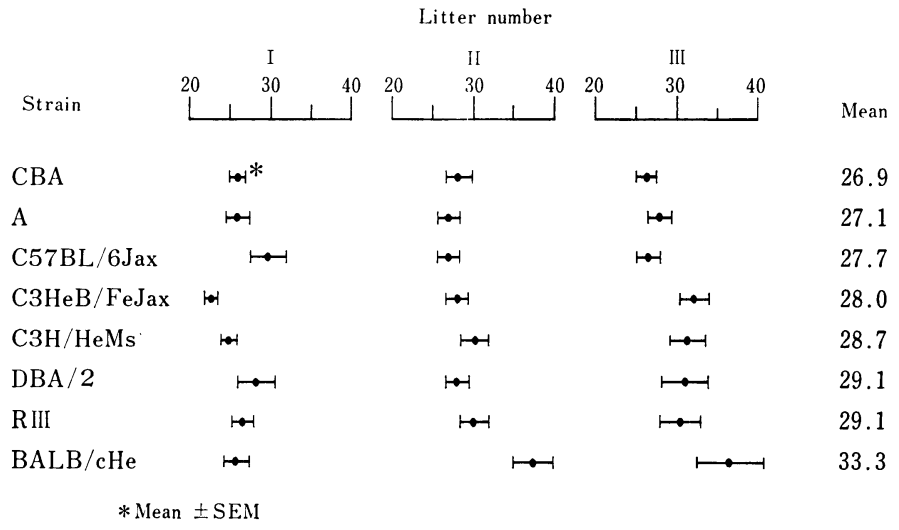

Fig. 1. Interval between littters (day).

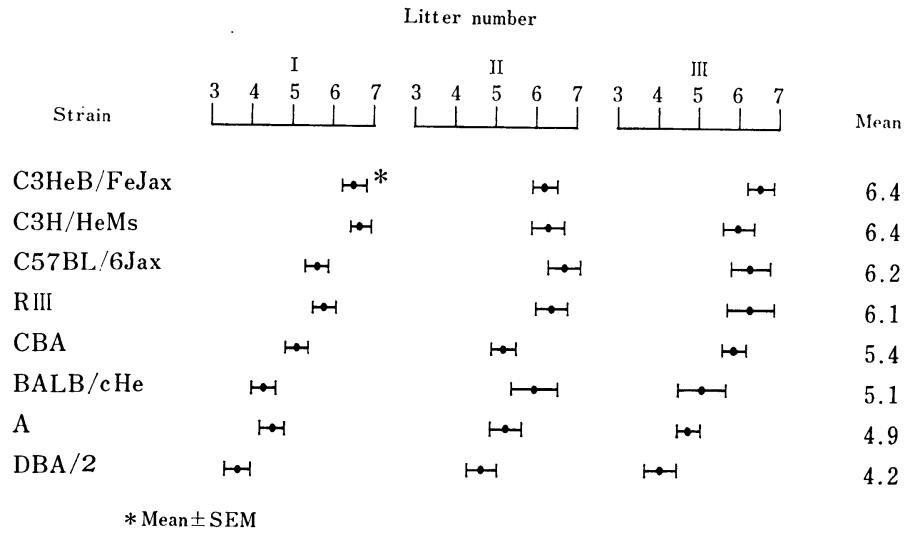

Fig. 2. Litter size (Number of live pups). 

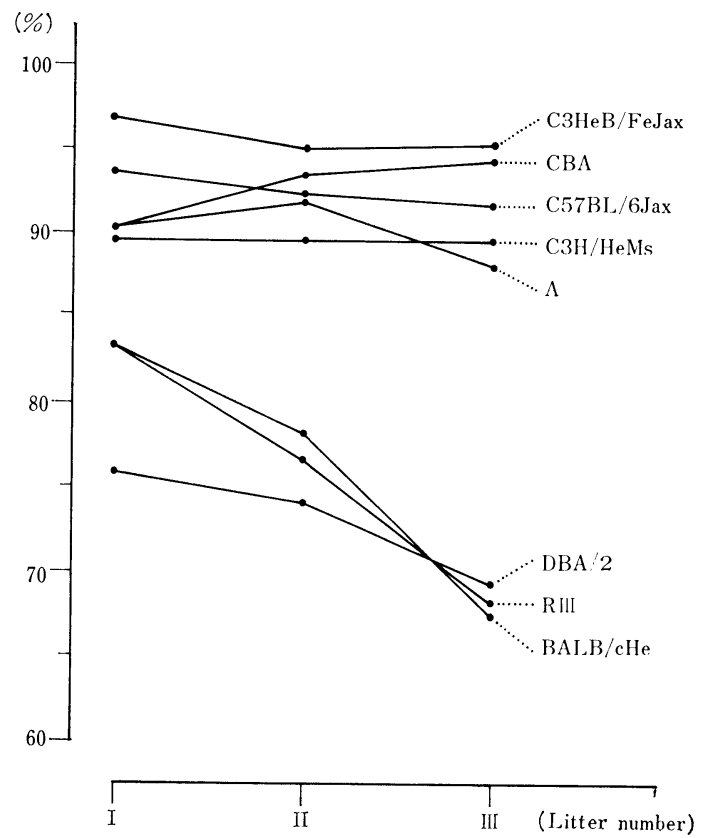

Actual number of normal parturition by each litter number Expected number of normal parturition by each litter number $\times 100$

Fig. 3. Normal parturition ratio.

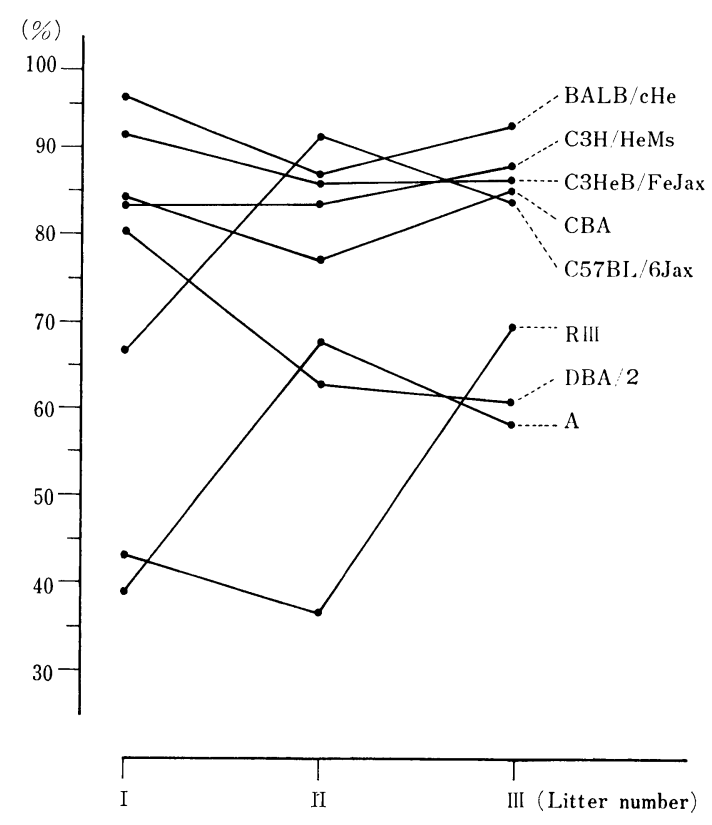

Fig. 4. Rearing ratio on day 20 .

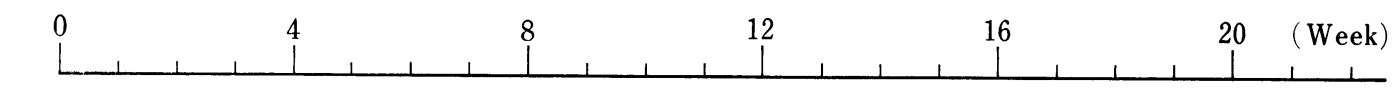

Group

10

20

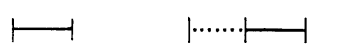

$|\cdots \cdots+|$

$\mid+\ldots . .+1$

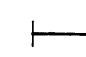

$|\cdots . .$.

$|\cdots \cdot+|$

$|\cdots \cdots \cdot+|$

3 。

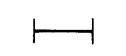

|.......

$\mid \cdots \cdots . .$.

|......... |.........

$4 \circ$

$\mapsto \quad \mid \cdots \cdots$

$|\cdots \cdots+|$

$|\cdots \cdots+|$

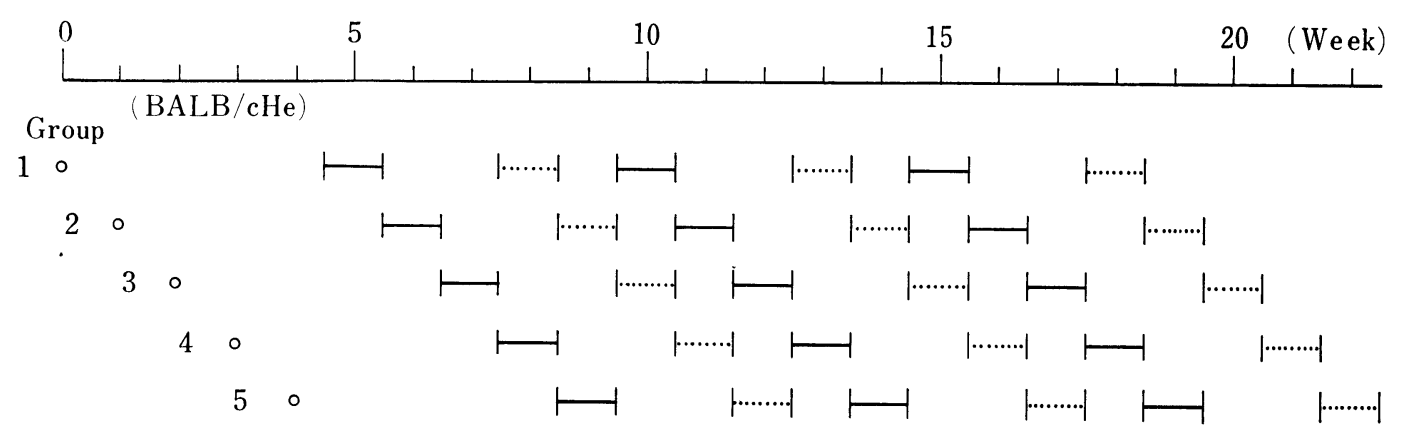

- Beginning of mating

$\longmapsto$ Parturition $\quad|\cdots \cdots . . .$.$| Weanling$

Fig. 5. Project for weekly production of weanling pups by concurrent pregnancy. 
Table 2. Pups' growth in each strain.

\begin{tabular}{|c|c|c|c|c|c|}
\hline \multirow{2}{*}{$\begin{array}{c}\text { Strain } \\
\text { (No of mice) }\end{array}$} & \multirow{2}{*}{$\begin{array}{l}\text { Litter } \\
\text { number }\end{array}$} & \multicolumn{3}{|c|}{ Av. pups' weight (g) } & \multirow{2}{*}{$\begin{array}{l}\text { Growth ratio } \\
\text { on day } 12^{1} \text { ) }\end{array}$} \\
\hline & & day 0 & day 12 & day 20 & \\
\hline \multirow{4}{*}{$\begin{array}{c}\text { C3HeB/FeJax } \\
(\mathrm{TC} 3 \mathrm{H}) \\
(31)\end{array}$} & 1 & $1.50 \pm 0.03(30) *$ & $7.25 \pm 0.23(29)$ & $9.01 \pm 0.23(29)$ & $385.0 \pm 14.0(29)$ \\
\hline & II & $1.59 \pm 0.03(29)$ & $7.34 \pm 0.17(28)$ & $9.02 \pm 0.23(28)$ & $361.6 \pm 10.1(28)$ \\
\hline & III & $1.58 \pm 0.03(30)$ & $7.37 \pm 0.23(30)$ & $9.62 \pm 0.29(29)$ & $366.6 \pm 13.2(30)$ \\
\hline & Mean & $1.56 \pm 0.02(89)$ & $7.32 \pm 0.12(87)$ & $9.22 \pm 0.15(86)$ & $370.8 \pm 7.3(87)$ \\
\hline \multirow{4}{*}{$\begin{array}{c}\mathrm{C} 3 \mathrm{H} / \mathrm{HeMs} \\
\quad(29)\end{array}$} & I & $1.44 \pm 0.03(26)$ & $7.17 \pm 0.18(26)$ & $8.62 \pm 0.28(26)$ & $401.3 \pm 13.5(26)$ \\
\hline & II & $1.57 \pm 0.04(26)$ & $7.38 \pm 0.17(26)$ & $8.53 \pm 0.29(25)$ & $375.9 \pm 13: 7(26)$ \\
\hline & III & $1.61 \pm 0.04(25)$ & $7.53 \pm 0.21(24)$ & $9.03 \pm 0.23(24)$ & $369.3 \pm 15.5(24)$ \\
\hline & Mean & $1.54 \pm 0.02(77)$ & $7.36 \pm 0.10(76)$ & $8.72 \pm 0.15(75)$ & $382.5 \pm 8.2(76)$ \\
\hline \multirow{4}{*}{$\begin{array}{c}\text { C57BL } / 6 \mathrm{Jax} \\
(32)\end{array}$} & $\mathrm{I}$ & $1.31 \pm 0.02(30)$ & $5.95 \pm 0.16(26)$ & $7.33 \pm 0.19(25)$ & $359.4 \pm 12.4(26)$ \\
\hline & II & $1.39 \pm 0.03(30)$ & $6.62 \pm 0.20(30)$ & $7.85 \pm 0.24(30)$ & $376.0 \pm 12.4(30)$ \\
\hline & III & $1.38 \pm 0.02(28)$ & $6.12 \pm 0.19(27)$ & $7.71 \pm 0.20(26)$ & $344.8 \pm 13.3(27)$ \\
\hline & Mean & $1.36 \pm 0.01(88)$ & $6.25 \pm 0.11(83)$ & $7.65 \pm 0.13(81)$ & $360.7 \pm 7.4(83)$ \\
\hline \multirow{4}{*}{$\begin{array}{l}\text { C B A } \\
(31)\end{array}$} & I & $1.55 \pm 0.03(29)$ & $7.37 \pm 0.17(27)$ & $8.35 \pm 0.23(27)$ & $374.5 \pm 11.2(27)$ \\
\hline & II & $1.49 \pm 0.03(31)$ & $7.04 \pm 0.21(30)$ & $8.20 \pm 0.20(29)$ & $382.2 \pm 10.3(29)$ \\
\hline & III & $1.45 \pm 0.03(31)$ & $6.67 \pm 0.13(31)$ & $8.07 \pm 0.21$ & $363.8 \pm 11.3(31)$ \\
\hline & Mean & $1.50 \pm 0.02(91)$ & $7.01 \pm 0.10$ & $8.20 \pm 0.12(87)$ & $373.3 \pm 6.3(87)$ \\
\hline \multirow{4}{*}{$\begin{array}{c}\mathrm{BALB} / \mathrm{cHe} \\
(30)\end{array}$} & I & $1.72 \pm 0.06(25)$ & $8.12 \pm 0.25(25)$ & $9.36 \pm 0.31(24)$ & $377.7 \pm 12.8$ \\
\hline & II & $1.71 \pm 0.06(22)$ & $7.92 \pm 0.30 \quad(21)$ & $9.27 \pm 0.34(20)$ & $371.0 \pm 13.4$ (21) \\
\hline & III & $1.62 \pm 0.07$ & $8.47 \pm 0.42(14)$ & $9.51 \pm 0.50$ & $425.9 \pm 28.4(14)$ \\
\hline & Mean & $1.69 \pm 0.04(61)$ & $8.13 \pm 0.18(60)$ & $9.36 \pm 0.21(58)$ & $386.6 \pm 9.9(60)$ \\
\hline \multirow{4}{*}{$\begin{array}{c}\text { A. } \\
(32)\end{array}$} & I & $1.15 \pm 0.02(28)$ & $5.28 \pm 0.24(16)$ & $6.31 \pm 0.42(15)$ & $356.7 \pm 19.2(16)$ \\
\hline & II & $1.29 \pm 0.03(30)$ & $5.95 \pm 0.14(25)$ & $6.81 \pm 0.18(25)$ & $364.1 \pm 10.3(25)$ \\
\hline & III & $1.28 \pm 0.02(26)$ & $6.21 \pm 0.16(20)$ & $7.12 \pm 0.12(20)$ & $378.4 \pm 12.4(20)$ \\
\hline & Mean & $1.24 \pm 0.02(84)$ & $5.86 \pm 0.11(61)$ & $6.79 \pm 0.14(60)$ & $368.8 \pm 7.7(61)$ \\
\hline \multirow{4}{*}{$\begin{array}{l}\text { R III } \\
(30)\end{array}$} & I & $1.34 \pm 0.02(25)$ & $6.51 \pm 0.16(15)$ & $7.75 \pm 0.26(13)$ & $381.9 \pm 9.9$ (15) \\
\hline & II & $1.36 \pm 0.03(21)$ & $6.29 \pm 0.23(9)$ & $8.00 \pm 0.42(9)$ & $339.7 \pm 19.7$ ( 9$)$ \\
\hline & III & $1.40 \pm 0.02(16)$ & $6.55 \pm 0.21(12)$ & $8.37 \pm 0.40(12)$ & $369.3 \pm 20.6(12)$ \\
\hline & Mean & $1.36 \pm 0.01 \cdot 62)$ & $6.47 \pm 0.11(36)$ & $8.03 \pm 0.20(34)$ & $367.2 \pm 9.5(36)$ \\
\hline \multirow{4}{*}{$\begin{array}{c}\text { D. B A } / 2 \\
\quad(25)\end{array}$} & I & $1.29 \pm 0.04(19)$ & $5.88 \pm 0.22(18)$ & $7.19 \pm 0.29(18)$ & $356.1 \pm 16.6 \quad(18)$ \\
\hline & II & $1.32 \pm 0.03(18)$ & $6.05 \pm 0.25(14)$ & $7.10 \pm 0.40$ & $351.5 \pm 15.8$ (14) \\
\hline & III & $1.39 \pm 0.05(15)$ & $6.07 \pm 0.19(11)$ & $6.85 \pm 0.30(11)$ & $321.3 \pm 16.6$ \\
\hline & Mean & $1.33 \pm 0.02(52)$ & $5.98 \pm 0.13(43)$ & $7.07 \pm 0.18$ & $345.7 \pm 9.7$ \\
\hline
\end{tabular}

Mean \pm SEM

1) Av. pups' wt. on day12-Av. pups' wt. on day $O$

$$
\text { Av. pups' wt. on day } \mathrm{O} \text {. on day } \mathrm{O}
$$

※umber of samples

前後まで下降し，正常分婏率の良いグループと悪いグル 一プに 2 大別された。この傾向は交配雌親の不妊率から も明らかであった。BALB/cHe, RIII, DBA/2 では抹 よそ30\%で他系よりはるかに高かった（Table 1)。

死産子率に执いては RIII が5.6\%でもっとも高く, $\mathrm{C} 3 \mathrm{HeB} / \mathrm{FeJax}$ は0.4\%でもっとも低かった。
12，20日齢育成率に怙いて BALB/cHe，C3H/HeMs， C3HeB/FeJax, CBA, C57BL/6Jax が12日齢で，85〜 $100 \%$ ，20日齢 80〜90\%であったのに対し，RIII，A， $\mathrm{DBA} / 2$ は12日齢70\%前後，20日齢で60\%前後であり， 育成率の良いグループと悪いグループとに 2 大別され た。また C57BL/6Jax, RIII, DBA/2, A では産次間 
Table 3. Example of number of parents or cages required for weekly production of weanling pups (100 per week).

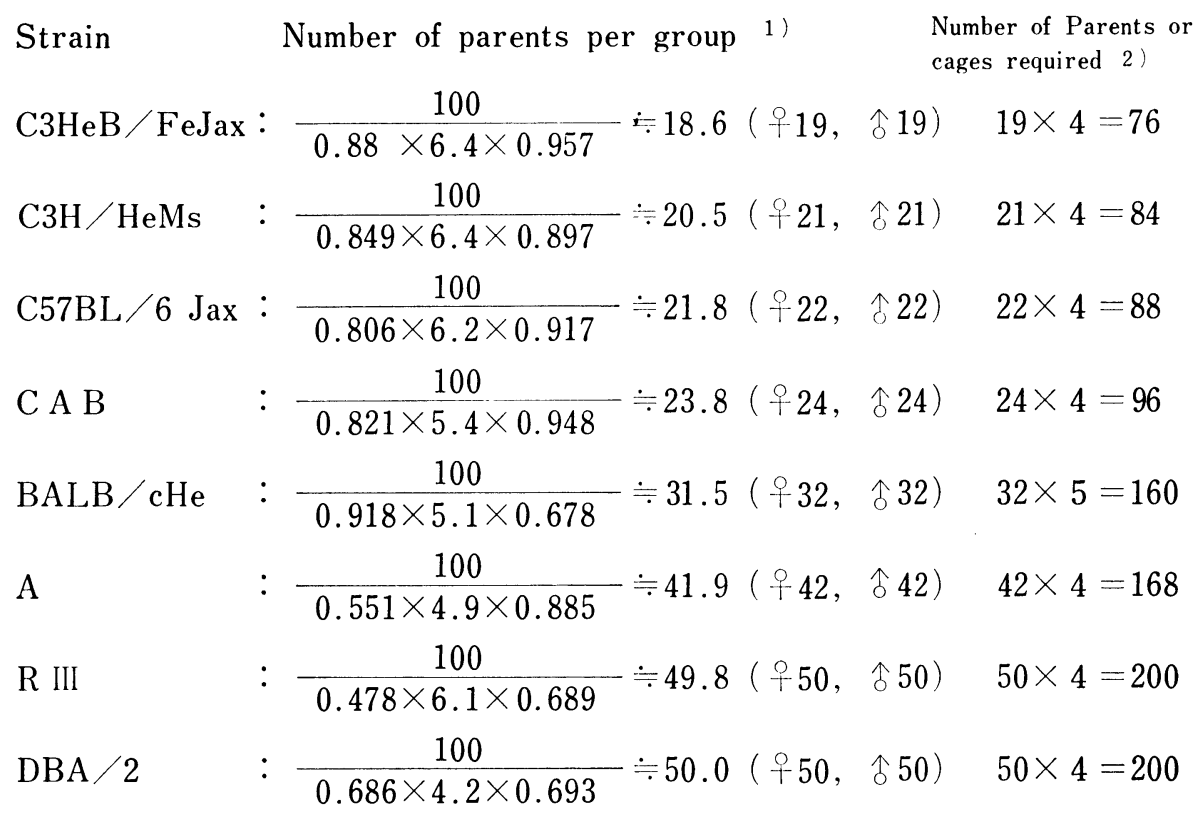

1 )

Number of weanling pups to be produced

Rearing ratio on day $20 \times$ Litter size $\times$ Normal parturition ratio

2 ) Number of parents per group $\times$ Ninmbe of grnuns

の変動が他の系統にくらべて大きかった (Fig. 4)。

Lane-Petterら[3]は母マウスの productivity の指 標として，

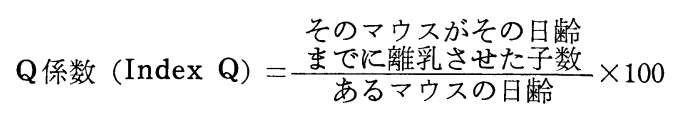

を提唱している。本実験では，交配開始日齢が，個体に よりまた系統により，必ずしも同一でなかったため，上 式の分母としては交配開始日ょりの日数を用いて各系統 のQ係数の算出を試みた。交配開始後 100 日および 150 日の $\mathrm{Q}$ 係数に拈いては, Table 1 に示したごとく $\mathrm{C} 3 \mathrm{HeB} / \mathrm{FeJax}, \mathrm{C} 3 \mathrm{H} / \mathrm{HeMs}, \ldots \ldots \mathrm{DBA} / 2$ の順で大 きい値を示した。

以上の結果を綜合して考察すると, 用いられた系統、 ウスの繁殖性は Table 1 の上から順に良好であると考 えられた。

各系統の子の発育に関する成績を Table 2 亿示し た。0，12，20日齢平均子体重に打いて，系統内産次間で 顕著な差異はみられなかったが，系統間には相違がみら れた。母体重の大きい $\mathrm{BALB} / \mathrm{cHe}, \mathrm{C} 3 \mathrm{HeB} / \mathrm{FeJax}$, $\mathrm{C} 3 \mathrm{H} / \mathrm{HeMs}$, CBA では各日齢の平均子体重も比較的 大きく，母体重の小さい $\mathrm{A}, \mathrm{DBA} / 2$ では小さい傾向を 示した。
12日齢増体率に颃いては系統間に差異のないところか ら，0日齢平均子体重の大小が 12 日齢ないし20日齢まで 持らこされるものと考觉られた。

\section{II. 計画生産についての一試案}

Tables 1，2 および Figs. 1〜4 亿示したような繁 殖成績から 交配分娩間隔, 産子数, 正常分娩率, 20日 齢育成率の平均值を用いて, 計画生産のための親ケージ 数を求めた。 $\mathrm{BALB} / \mathrm{cHe}$ を除く 7 系統では, 交配分婏 間隔が 1 産あたり約 4 週間であることから，生産親の編 成は 4 群とし， 1 週間ずつずらして交配を開始すること により, 毎週の出産, 離乳が期待できることになる。 $\mathrm{BALB} / \mathrm{cHe}$ のみは交配分婏間隔が約 5 週間であり, し たがって 5 群必要になる (Fig. 5)。1 群の交配動物数 は,

\section{$\frac{\text { 生 産 数 }}{\text { 育成率 } \times \text { 産子数 } \times \text { 分婏率 }}$}

によって知ることができ, 生産ケージ数は, 1 群の交配 動物数と編成群数の積を求めることにより算出される。

一例として, 毎週 100 匹の動物を生産する場合の具体 例を示すと Table 3 のごとく $\mathrm{C} 3 \mathrm{HeB} / \mathrm{FeJax}, \mathrm{C} 3 \mathrm{H} /$ HeMs, C57BL/6Jax, CBA, BALB/cHe, A, RIII, DBA/2 では，それぞれ 76，84，88，96,160，168，200， 
200 ケージを必要とした。そしてこの順位は，Iで明ら かになった繁殖性の順位と全く同じであり，系統によっ ては, 他系統の倍以上の生産親（ケージ数）を必要とす る結果が得られた。

要 約

系統マウスの生産を効率よく行ならための基礎データ を得る目的で, 当研究所で系統繁殖している 8 系統のマ ウスの繁殖性について, 交配分娩間隔, 産子数, 正常分 婏率, 分娩時母体重, $0,12,20$ 日龄平均子体重, 12 日 齢増体率, 12, 20日齢育成率, 繁殖不能個体率, 死産子 率などを調べ，これらの成績に基づいた生産方法，とく に追いかけ妊娠方式による計画生産についての試案を作 成した。

分娩間隔において BALB/cHe のみが約 5 週間で長か ったが，他の系統は約 4 週間であった。産子数に括い ては系統内産次間で顕著な変動はみられなかったが, 系統間に括いては相違が認められた。正常分婏率では C3HeB/FeJax, CBA, C57BL/6Jax, C3H/HeMs, A では90\%前後であったが, BALB/cHe, RIII, DBA/2 は70\%であり，良いグループと悪いグループに 2 大別さ れた。20日齢育成率でも RIII，A が他系とくらべて悪 かった。

以上の成績を基にして, 週単位の生産を基準とした追 いかけ妊娠による計画生産の試案を作成した。分娩間隔 の成績から生産群の編成は BALB/cHeを 5 群, 他の系
統は 4 群を設け, 各系統の分姺率, 産子数, 育成率の平 均值を用いて, 毎週 100 匹の動物を生産するのに必要な 生産親ケージ数を算出したところ, C3HeB/FeJax, C3H /HeMs, C57BL/6Jax, CBA, BALB/cHe, A, RIII, DBA/2 ではそれぞれ 76, 84,88，96，160，168，200， 200 ケージとなった。

本実験の一部は文部省科学研究助成金（がん特別研究 I , No. 90183) によるものである。

\section{文献}

[1] Festing, M. (1968). Some aspects of reproduction performance in inbred mice. Lab. Anim. 2 : 89-100

[2] Festing, M. (1969). Inbred mice in research. Nature $221: 716$

[3] Lane-Petter, W., Brown, A. M., Cook, M. J., Porter, G. and Tuffery, A. A. (1959). Measuring productivity in breeding of small animals. Nature 183 : 339

[4] Nagasawa, H., Fujimoto, M., Iwahashi, H. and Kuretani, K. (1967). Normal growth and reproduction of a high and a low mammary tumor strains of mice. GANN $58: 115-123$

[5]田嶋嘉雄 (編) (1970). 実験動物学総論, 朝倉書 店, 東京. pp. 151-202 